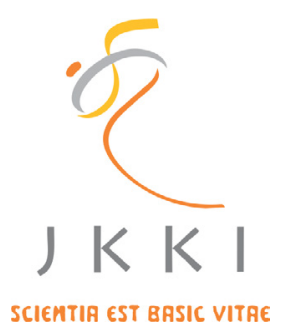

Jurnal Kedokteran dan Kesehatan Indonesia

Indonesian Journal of Medicine and Health

Journal homepage : www.journal.uii.ac.id/index.php/JKKI

\title{
Thoracic ectopia cordis: A case report
}

Danang Himawan Limanto*1, Heroe Soebroto ${ }^{2}$

${ }^{1}$ Department of Cardiothoracic and Vascular Surgery, Faculty of Medicine, Universitas Airlangga, Airlangga University Hospital, Surabaya, Indonesia

${ }^{2}$ Department of Cardiothoracic and Vascular Surgery, Faculty of Medicine, Universitas Airlangga, Dr soetomo General Academic Hospital, Surabaya Indonesia

Case Report

\begin{tabular}{|c|c|}
\hline & ABSTRACT \\
\hline ARTICLE INFO & Ectopia Cordis is a congenital anomaly in which the heart is located \\
\hline $\begin{array}{l}\text { Keywords: } \\
\text { thoracic ectopia cordis, } \\
\text { congenital heart defect, } \\
\text { bovine pericardium }\end{array}$ & $\begin{array}{l}\text { unclear with the incidence rate of } 8: 1,000,000 \text { live births. Clinical } \\
\text { manifestations usually present as severe sepsis respiratory distress due } \\
\text { to heart failure as a result of an intrinsic abnormality of the heart which }\end{array}$ \\
\hline $\begin{array}{l}\text { *Corresponding author: } \\
\text { dananglimanto@gmail.com } \\
\end{array}$ & $\begin{array}{l}\text { makes the management more challenging. Five days-old female newborn } \\
\text { was referred to our hospital by a local doctor with "beating lump" outside }\end{array}$ \\
\hline DOI : 10.20885/JKKI.Vol11.Iss1.art15 & her chest. The diagnosis of complete thoracic ectopia cordis was made by \\
\hline $\begin{array}{l}\text { History: } \\
\text { Received: October 10, } 2019 \\
\text { Accepted: April 20, } 2020 \\
\text { Online: April 30, 2020 }\end{array}$ & $\begin{array}{l}\text { clinical examination, chest x-ray, and echocardiography. The Echo showed } \\
\text { complete AV canal, ASD, mild pulmonary stenosis, and atrioventricular } \\
\text { valve regurgitation. Palliative surgery was then undertaken with the }\end{array}$ \\
\hline $\begin{array}{l}\text { Copyright @2020 Authors. } \\
\text { This is an open access article } \\
\text { distributed under the terms } \\
\text { of the Creative Commons At- } \\
\text { tribution-NonCommercial } 4.0 \\
\text { International Licence (http:// } \\
\text { creativecommons.org/licences/ } \\
\text { by-nc/4.0/). }\end{array}$ & $\begin{array}{l}\text { initial goal to limit exposure and prevent further infection. The heart is } \\
\text { covered with bovine pericardium sutured along the edge of the chest wall } \\
\text { defect. Ectopia cordis is rare and has a poor prognosis especially thoracic } \\
\text { and cervical types. Definitive surgery, to replace the heart to the thoracic } \\
\text { cavity, is difficult to perform because of the hypoplastic thoracic cavity. } \\
\text { Attempt to do palliative surgery, such as covering the heart with either } \\
\text { skin flap or other material, becomes the choice of treatment in this case } \\
\text { although there is no evidence reported of adulthood survivors. }\end{array}$ \\
\hline
\end{tabular}

$\overline{\text { Ektopia Cordis adalah anomali kongenital di manajantung terletaktidaknormal di luar rongga toraks. Etiologi }}$ cacat ini masih belum jelas dengan tingkat kejadian 8: 1.000.000 kelahiran hidup. Manifestasi klinis biasanya timbul sebagaigangguan pernapasan sepsis berat akibatgagaljantung akibat kelainan intrinsikjantung yang membuat penatalaksanaan lebih menantang. Bayi perempuan yang baru berusia lima hari dirujuk ke rumah sakit kami oleh dokter setempat dengan "benjolan" di luar dadanya. Diagnosis dari ectopia cordis toraks lengkap dibuat dengan pemeriksaan klinis, rontgen dada, dan ekokardiografi. Echo menunjukkan saluran AV lengkap, ASD, stenosis paru ringan, dan regurgitasi katup atrioventrikular. Operasi paliatif kemudian dilakukan dengan tujuan awal untuk membatasi pajanan dan mencegah infeksi lebih lanjut. Jantung ditutup dengan pericardium bovine yang dijahit di sepanjang tepi dinding dada yang cacat. Cordic ectopia merupakan kasus yang jarang dan memiliki prognosis yang buruk terutama tipe toraks dan serviks. Pembedahan definitif, untuk menggantikan jantung ke rongga toraks, sulit dilakukan karena rongga toraks hipoplastik. Mencoba melakukan pembedahan paliatif, sepertimenutupijantung denganlipatan kulitataubahanlain, menjadipilihan perawatan dalam kasus ini meskipun tidak ada bukti yang dilaporkan tentang orang dewasa yang selamat.

\section{INTRODUCTION}

Ectopia Cordis (EC) is a condition in which the heart lies outside the thoracic cavity. Shao tsu divided EC based on its position into thoracic, thoracoabdominal, and cervical EC. ${ }^{1,2}$ Abdominal $\mathrm{EC}$ is then added to the classification by Blatt 
and Khoury. ${ }^{2,3}$ Thoracic EC is defined by the position of the heart completely anterior to the undeveloped sternum. The heart in thoracic EC is not covered by either skin or membrane (pericardium), therefore it is distinguished from cleft sternum where the heart is still inside the thoracic cavity and covered with the skin but with no sternal bone. ${ }^{2,4}$

Thoracoabdominal EC is usually associated with omphalocele that is also covered by the same membrane. Omphalocele may coexist because of ventral body wall defect in the thoracoabdominal region. Along with other specific defects, coexistence of thoracoabdominal EC and omphalocele is called Pentalogy of Cantrell. The required features of the pentalogy of Cantrell are a cleft lower sternum, a half-moon anterior diaphragmatic defect, absence of the parietal pericardium, adjacent or completely separate omphalocele, ventral hernia or diastasis recti, and in a major form of congenital heart disease.,5 Abdominal EC is a rare presentation in which is often described as the lower presentation of thoraco-abdominal type. The presentation of both types are relatively similar. ${ }^{1,2,6}$ Cervical type has been defined as a separate entity from the thoracic type. The heart is displaced more superiorly than thoracic type and severe craniofacial deformity often coexists. ${ }^{2}$

Incidence of EC, as described by Khoury, is estimated as small as eight cases in 1,000,000 live births in which $65 \%$ of them is the thoracic type. ${ }^{3,6}$ Etiology of this defect is still unclear. The theory which is believed that cause EC and Pentalogy of Cantrell (spectrum of EC), is caused by disorders that occur before or just after differentiation of embryonic primitive mesoderm into splanchnic and somatic layers that leads to failure of ventral body wall formation. ${ }^{5,7-9}$ In the true EC, the failure of sternal fusion seems to be secondary to the malposition of the heart itself. ${ }^{7}$ Another theory said that the rupture of chorionic membrane at 3-weeks' gestation cause amniotic band constricts the normal descent of the heart which is then make it impossible to enter thoracic cavity. ${ }^{4,7}$

Clinical presentations reported from several cases are focused on intrinsic cardiac anomaly and sepsis. ${ }^{4,7,10}$ Infants mostly present with shortness of breath due to pumping mechanism disturbances due to associated intrinsic anomalies of the heart. Fever is caused by the absence of skin and pericardium, thus making it susceptible to bacterial contamination and may lead to sepsis. As long as atmospheric contact is not repaired, treatment of sepsis itself becomes difficult to manage..$^{2-4,6}$

Definitive cardiac and thoracic cage reconstruction is very challenging, owing to the inability to enclose the ectopic heart within a hypoplastic thoracic cavity, especially in thoracic type. Some authors said attempts for corrective cardiac surgery, if necessary, were always undertaken before palliative closure. ${ }^{2,11}$ Attempt to do definitive thoracic reconstruction surgery is difficult, therefore palliative closure surgery becomes the choice of treatment in EC cases. ${ }^{11}$ Palliative surgery in a patient with EC is focused on covering the heart from the atmospheric contact. The first successful staged repair of EC was achieved by Koop in 1975. Several early cases document the long-term viability of individuals with thoracoabdominal EC with intact skin coverage despite the abnormal location and coverage of the heart. ${ }^{4}$

The usage of the skin for primary closure is the best option. The biomaterial, however, becomes the choice of material when the skin is inadequate. Biomaterial such as bovine pericardium has replaced synthetic material such as surgical mesh to be used as patches in surgery because of its compatibility and less complication. ${ }^{12,13}$ It has several advantages such as dependable suture retention, less suture line bleeding, ideal operative handling characteristic, and less possibility to develop inflammation due to foreign body implantation. Available bovine pericardium patches are processed to be acellular, preventing reaction of bovine proteins into the host which can trigger inflammatory response. ${ }^{12}$

\section{CASE REPORT}

Five-days-old female full-term newborn came 
to our hospital complaining of pulsating mass on her chest. She was referred by a local hospital after spontaneous vaginal delivery by a local midwife. She cried immediately after birth, no cyanotic or shortness of breath were reported. Apgar score was 8 - 9. Amniotic fluid was clear. There were no significant complaints during pregnancy except for her mother had a common cold for five days at the last trimester. Consent was taken from the legal guardian to study and publish the case.
Stable hemodynamics were documented when she came. She had shortness of breath, her respiratory rate was 56 times per minute. The heart lies outside the thoracic cavity with the apex pointing towards her neck. Right atrium, left atrium, right ventricle, and left ventricle were identified completely exposed with no skin or membrane or pericardium coverage as seen in Figure 1. Cleft lip and palate (CLP) were also identified. There was no abdominal wall defect found. There was no other defect reported.

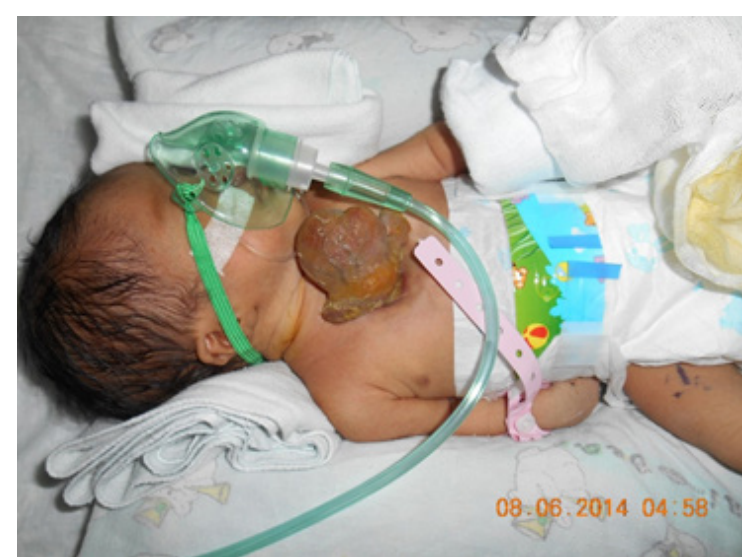

Figure 1. The clinical presentation. Four chambers of the heart lies completely outside thoracic cavity

Chest x-ray, echocardiography, and a blood test were performed. Blood test showed elevated white blood cells (WBC) count and elevated C-Reactive protein. Chest x-ray showed the heart was completely outside the thoracic cavity sized $5 \times 5.5 \mathrm{~cm}$ with small thoracic cavity and no abnormality of the lung detected as seen in Figure 2. Echocardiography showed complete atrioventricular canal, small secundum atrial septal defect, mild pulmonary stenosis, and atrioventricular regurgitation.

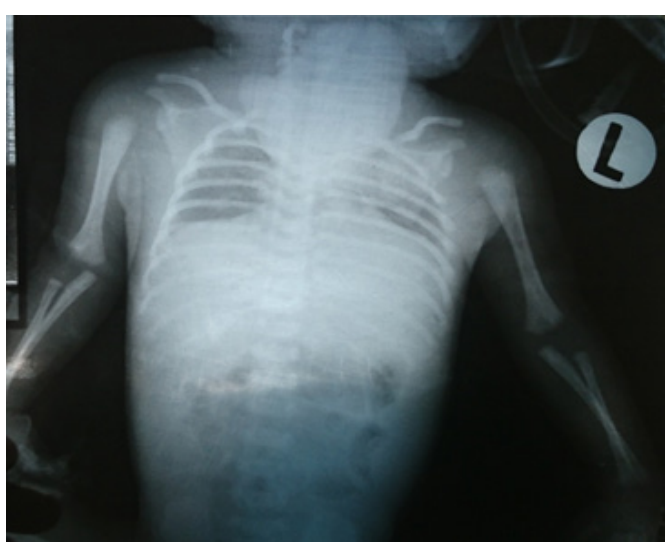

Figure 2. Chest $\mathrm{x}$-ray showed the thoracic cavity is relatively small compared to the size of the ectopic heart 
This patient was then diagnosed with complete thoracic ectopia cordis and labiopalatoschizis. Palliative surgery in the aim of covering the exposed heart using bovine pericardium, material that is commonly used in reconstruction in cardiac surgery, was undertaken in the operating room. Identifications during surgery include: the heart was completely outside the thoracic cavity, great vessels arose from the heart directly enter the thoracic cavity, and there was no sternum. The heart was then irrigated with saline, and eventually, the bovine pericardium was sutured along the freshened skin edge using running 5-0 polypropylene suture. There was no significant hemodynamic deterioration during or after the procedure. The surgical details are depicted in Figure 3.

The patient was transferred to the NICU after surgery with stable hemodynamic. She was lightly sedated during the first post-operative day. Decreased WBC count was documented during the first and second preoperative day. It was also followed by the decreasing of the CRP and procalcitonin level. Antibiotics were continued according to the infection control team.
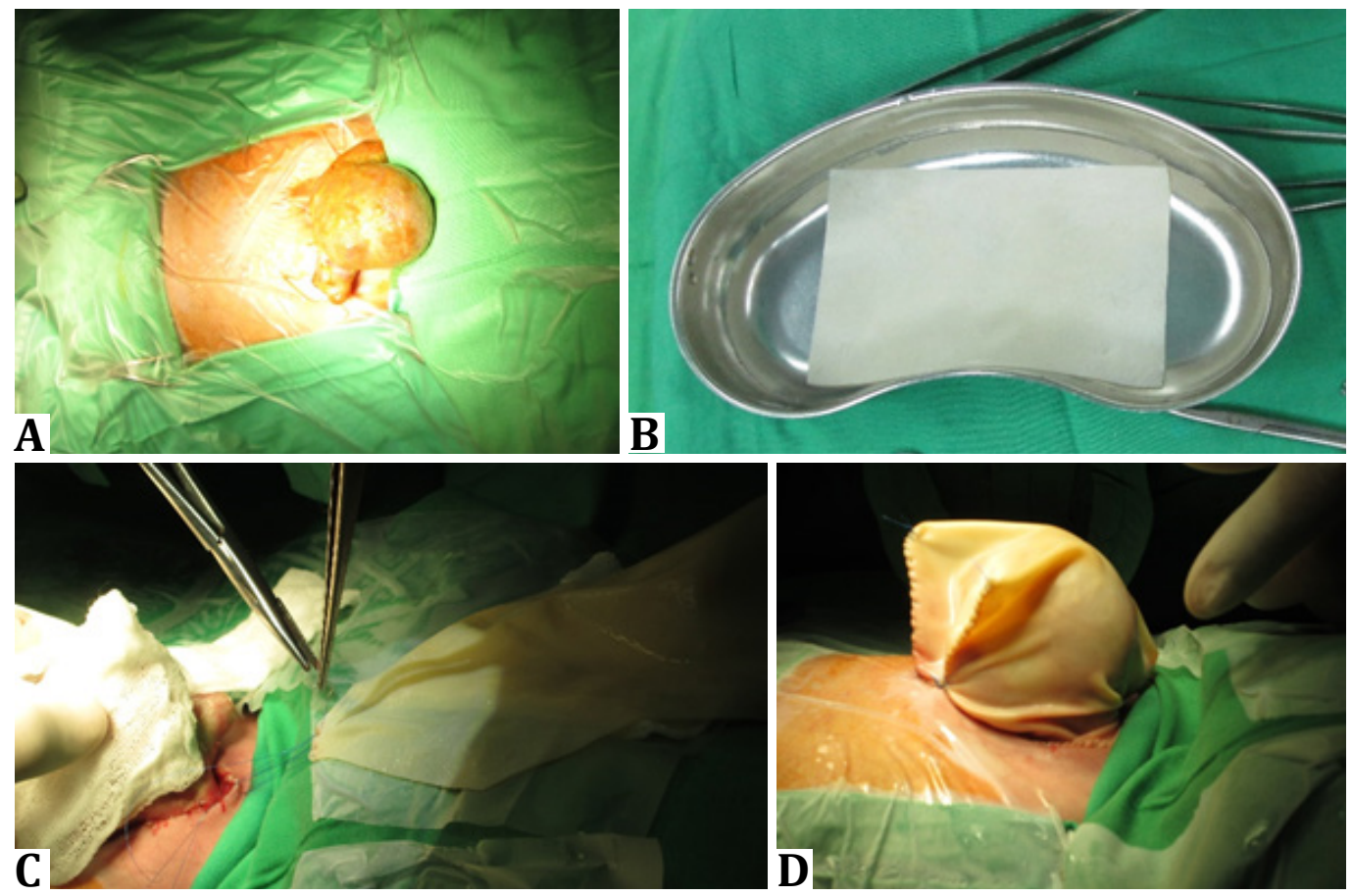

Figure 3. Operative finding. (A) The heart is completely outside thoracic cavity without pericardium covering. (B) Bovine pericardium. (C) Bovine pericardium being stitched to the edge of the freshened skin. (D) The heart is covered with the new pericardium

Unfortunately, on the third postoperative day, her blood pressure decreased gradually. Bedside echocardiography was performed and revealed biventricular failure due to large intracardiac shunts. Inotropic supports were administered and increased accordingly, but the patient eventually died on postoperative day five due to heart failure.

\section{DISCUSSION}

Definitive surgery is difficult or sometimes impossible to be done in these patients. It is because the hypoplastic thoracic cavity makes it hard for the surgeon to place the heart back to the thoracic cavity without significant hemodynamic problems. A successful palliative surgical correction, according to Hornberger et $\mathrm{al}$, has to meet two requirements, there are no associated extracardiac abnormalities and there is enough skin in the midline area for closure. Hornberger reported thirteen EC cases that meet those criteria, underwent palliative surgery and 
survived more than one-year-old. Although he did not mention the closure technique using direct closure or else. Until now, there is no EC case reported that survive until adulthood. ${ }^{11}$ The patient on this case has abnormal angulation of great vessels coexist with a hypoplastic thoracic cavity that makes definitive surgery is not an option. Attempt to place the heart back will constrict the heart and bend the great vessels that will result in the altered pumping function of the heart and it eventually leads to rapid hemodynamic deterioration. Palliative surgery was then undertaken. This surgery was intended to control contamination by limiting heart contact with the atmosphere. The bovine pericardium was used due to lack of skin in the midline area for direct closure (skin-flap). It is chosen over synthetic mesh because of its compatibility and durability. The procedure was done without significant hemodynamic disturbances.

Aetiology of this defect is still unclear. The hypothesis that is mostly believed as a cause of this defect, is the failure of mesodermal maturation in fetal development. This embryogenesis disorder fails ventral body wall closure in general. When it happens in the thoracic cavity, it becomes thoracic EC or thoracoabdominal EC. In the situation of Pentalogy of Cantrell, it is also associated with the development of omphalocele., ${ }^{5,9}$ This patient has two separate ventral body wall closure failures which are anterior thoracic wall defect and CLP.

Diagnosis can be made right after the baby was born. Even though the diagnosis of EC can be made by physical examination only, other tests should be performed to detect other anomalies includes the anomaly of the heart itself., ${ }^{2,45}$ Echocardiography is an excellent diagnostic tool to describe the structural anatomy of the heart. The most common associated defect is VSD and Tetralogy of Fallot, followed by other frequent defects which are ASD, left ventricular diverticulum, pulmonary stenosis or atresia, and other less frequent defects. ${ }^{7,10}$ This patient has some less frequent aforementioned intrinsic anomalies of the heart detected by echocardiography. This combination of intrinsic anomalies and malposition make the heart does harder work to pump enough cardiac output for both systemic and pulmonary circulation.

This patient died in post-operative day five due to heart failure. As surgeons struggled to control contamination, the intrinsic heart defect itself worsen subsequently. The complete atrioventricular canal itself resulted in a large left to right shunt that might lead to pulmonary overflow. Atrioventricular valve regurgitation made the overloading heart even worse that eventually led to decompensated heart failure.

The prognosis of this defect anomaly is poor especially for thoracic and cervical type. This is because of the malposition of the heart. The more extreme its position the poorer the prognosis. Thoraco-abdominal type, however, has better prognosis because of the slight abnormality of the gross anatomy of the heart and great vessels, but the physician needs to consider the other intrinsic structural defects of the heart itself to determine the prognosis in general. Atmospheric exposure of the heart makes it vulnerable to bacterial contamination that can leads to infection or even severe sepsis, therefore this condition also contributes in patient's morbidity and mortality. $2,4,7,10$

\section{CONCLUSION}

Thoracic EC usually presents with thoracic cage hypoplasia that leads to inability to undertake the definitive pathway. Infection containment becomes the main purpose in managing this case. Bovine pericardium, as a common material used in cardiac surgery, works as a cover that provides protection from the atmospheric contamination. Unfortunately, prognosis does not solely depend on Infection control. Intrinsic structural cardiac defects play enormous role in the course of the disease. The management of this case remains a challenge to manage the cardiac defect and contain the infection subsequently.

\section{CONFLICT OF INTEREST}

Authors declare no conflict of interest. 


\section{ACKNOWLEDGEMENT}

None.

\section{REFERENCES}

1. Shao-tsu VL. Ectopia cordis congenita. The Journal of thoracic and cardiovascular surgery. 1957;5(3):197-212.

2. Grosfeld JL. O'Neill JA, Fonkalsrud EW CA. Pediatric surgery. 6th ed. Philadelphia: Mosby; 2006.

3. Khoury MJ, Cordero JF, Rasmussen S. Ectopia cordis, midline defects and chromosome abnormalities: An epidemiologic perspective. American journal of medical genetics.1988; 30(3):811-7.

4. Puri P. Newborn surgery. 2nd ed. London: Arnold; 2003.

5. Cantrell JR, Haller JA, Ravitch MM. A syndrome of congenital defects involving the abdominal wall, sternum, diaphragm, pericardium and heart. Surgery, gynecology \& obstetrics. 1958;107(5):602-614.

6. Amitabh P, Sharan R, Talapatra A. Ectopia cordis. Journal of clinical neonatology 2012;1(3):166-167.

7. Puvabanditsin S, Stefano VD, Garrow E, Wong R, Eng J, Balbin J. Ectopia cordis. Hong Kong medical journal. 2013;19(5):447-450.

8. Engum SA. Embryology, sternal clefts, ectopia cordis, and cantrell's pentalogy. Seminars in pediatric surgery. 2008;17(3):154160.

9. Brewer S, Williams T. Loss of AP-2 a impacts multiple aspects of ventral body wall development and closure. Developmental Biology.2004;267:399-417.

10. Magadum S, Shivaprasad H, Dinesh K, Vijay K. Incomplete cantrell's pentalogy A case report. Indian Journal of Surgery. 2013;75:350-352.

11. Hornberger LK, Colan SD, Lock JE, Wessel DL, Mayer JJE. Outcome of patients with ectopia cordis and significant intracardiac defects. Circulation. 1996;94(9 Suppl):II32-7.

12. Li X, Guo Y, Ziegler KR, Model LS, Eghbalieh SD, Brenes RA, Kim ST, Shu C, Dardik A.. Current usage and future directions for the bovine pericardial patch. Annals of vascular surgery. 2011;25(4):561-8.
13. D'Ambra L, Berti S, Feleppa C, Magistrelli P, Bonfante $\mathrm{P}$, Falco E. Use of bovine pericardium graft for abdominal wall reconstruction in contaminated fields. World journal of gastrointestinal surgery. 2012;4(7):171. 